\title{
Rapid Conversion of Chicken Feather to Feather Meal Using Dimeric Keratinase from Bacillus licheniformis ER-15
}

\section{Ekta Tiwary and Rani Gupta*}

Department of Microbiology, University of Delhi, South Campus, New Delhi, India-110021

\begin{abstract}
Dimeric keratinase from Bacillus licheniformis ER-15 completely degraded $25 \mathrm{~g}$ boiled native chicken feather to feather meal within $8 \mathrm{~h}$ at $\mathrm{pH} 8,50^{\circ} \mathrm{C}$ and $150 \mathrm{rpm}$. Feather degradation was a linear function of enzyme concentration and $2.5 \mathrm{~g}$ chicken feather was degraded in presence of $1200 \mathrm{U}$ keratinase. Process for feather meal production comprised soaking of $25 \mathrm{~g}$ feather in $250 \mathrm{ml}$ water followed by boiling for $10 \mathrm{~min}-20 \mathrm{~min}$ before enzyme addition. Feather meal thus produced was dried at $80^{\circ} \mathrm{C}$ and ground to obtain feather meal powder. Feather meal contained $14 \%$ nitrogen, $44 \%$ carbon with all essential amino acids and showed $73 \%$ in-vitro digestibility.
\end{abstract}

Keywords: Bacillus licheniformis; Feather Degradation; Feather Meal, in-vitro Digestibility, Keratinase

\section{Introduction}

Feather is protein rich waste product of poultry processing industries which are being generated in billion of tons every year [1-4]. These feathers are generally land filled or burnt which cause environmental problems [4]. Feather are also degraded to feather meal which is used as animal feed, organic fertilizers, feed supplements because it is made up of $>90 \%$ protein and rich in hydrophobic amino acids and important amino acids like cystine, arginine, threonine [5,6]. Most popular method of feather meal production is by hydrothermal process where feather are cooked under high pressure at high temperature. However, hydrothermal treatment, results in destruction of essential amino acids like methionine, lysine, tyrosine, tryptophan and has poor digestibility and low nutritional value $[7,8]$. In this respect, microbial degradation of feather into feather meal has gained importance and new microbes are being looked upon for efficient degradation of feather. Feather are degraded during fermentation process where consortium of thermophilic/mesophilic bacterial cultures such as Bacillus, Streptomyces, Vibrio, Chryseobacterium strains are used [4,6,9]. During fermentation not more than $0.5-2 \% \mathrm{w} / \mathrm{v}$ can be used and also essential amino acids are utilized by micro-organism which decreases the nutritional value of feather meal. To combat this, focus of the research is changing towards developing of enzymatic methods of feather degradation using special class of proteases, the keratinases. Till date not more than $10 \%$ feather degradation is reported in the presence of keratinases however a novel dimeric keratinase from Bacillus licheniformis ER-15 was observed to degrade feather completely into feather meal [10]. Here various process parameters for enzymatic degradation of feather to feather meal have been standardized. Amino acid analysis and in-vitro digestibility of the feather meal is also compared with existing reports.

\section{Material and Methods}

Chemicals used for buffer and medium were obtained from Sisco Ranbaxy Laboratory (SRL, India). Soy flour and chicken feather were collected from local market only.

\section{Analytical methods}

Keratinase assay: Keratinase activity was measured using 20mg feather, $1 \mathrm{ml}$ of properly diluted enzyme and $4 \mathrm{ml}, \mathrm{pH} 10$ buffer $(50 \mathrm{mM}$ Glycine- $\mathrm{NaOH}$ buffer). Reaction mixture was incubated at $60^{\circ} \mathrm{C}$ for $1 \mathrm{~h}$ and stopped with $4 \mathrm{ml}$ of $5 \% \mathrm{w} / \mathrm{v}$ trichloro acetic acid (TCA) followed by incubation at room temperature for $30 \mathrm{~min}$ and centrifugation at 8000rpm for 10min. Absorbance of supernatant was measured at A280. Similarly, control reaction was set up with $1 \mathrm{ml}$ of $5 \%$ w/v TCA Enzyme unit was defined as amount of enzyme required to release protein equivalent to absorbance of 0.01 from feather keratin under standard assay condition [2].

Protein determination: Protein in supernatant was measured at A280 and 1 absorbance was considered as $1 \mathrm{mg} / \mathrm{ml}$ protein using bovine serum albumin as standard.

\section{Production and downstream processing of keratinase from Bacillus licheniformis ER-15}

Enzyme production: Keratinase was produced in soyflour feather medium in $60 \mathrm{~h}$ as reported earlier [10]. A loopful bacterial culture was inoculated in $50 \mathrm{ml}$ nutrient broth in $250 \mathrm{ml}$ Ehrlenmeyer flask, grown at $37^{\circ} \mathrm{C}, 200 \mathrm{rpm}$ for $16 \mathrm{~h}$ and used as seed culture. This seed culture was again grown in nutrient broth for $16 \mathrm{~h}$ in similar conditions and used as inoculum for production medium. Four hundred $\mathrm{ml}$ of production medium in $2 \mathrm{~L}$ flask $(0.4 \% \mathrm{w} / \mathrm{v}$ soyflour, $3 \% \mathrm{w} / \mathrm{v}$ glucose, $0.3 \mathrm{w} / \mathrm{v}$ $\mathrm{KH} 2 \mathrm{PO} 4,0.9 \% \mathrm{w} / \mathrm{v} \mathrm{K} 2 \mathrm{HPO} 4,0.5 \% \mathrm{w} / \mathrm{v}$ feather) was inoculated with $4 \%$ $\mathrm{v} / \mathrm{v}$ inoculum and incubated at $250 \mathrm{rpm}, 37^{\circ} \mathrm{C}$ for $60 \mathrm{~h}$.

Sedimentation and microfiltration: After $60 \mathrm{~h}$ of production, fermentation broth was collected in a beaker and kept at room temperature in static condition for $24 \mathrm{~h}$. Most of the bacterial cells were settled along with feather meal at the bottom of beaker, supernatant was decanted and micro filtered through $0.2 \mu$ filters (MDI, India) using vacuum pump. This micro filtered supernatant was concentrated and used as enzyme.

Enzyme concentration and shelf life: Micro filtered supernatant was concentrated using $85 \%$ saturation of ammonium sulphate. Precipitated enzyme was collected after centrifugation, dissolved in $\mathrm{pH} 7$

*Corresponding author: Rani Gupta, Department of Microbiology, University of Delhi, South Campus, New Delhi, India-110021; Tel: +91-11-24111933; Fax: +91 11-24115270; E-mail: ranigupta15@rediffmail.com

Received April 17, 2012; Accepted May 16, 2012; Published May 18, 2012

Citation: Tiwary E, Gupta R (2012) Rapid Conversion of Chicken Feather to Feather Meal Using Dimeric Keratinase from Bacillus licheniformis ER-15. J Bioprocess Biotech 2:123 doi: 10.4172/2155-9821.1000123

Copyright: @ 2012 Tiwary E, et al. This is an open-access article distributed unde the terms of the Creative Commons Attribution License, which permits unrestricted use, distribution, and reproduction in any medium, provided the original author and source are credited. 
phosphate buffer and stored at $4^{\circ} \mathrm{C}$. concentrated enzyme was used for feather meal production after required dilution. Enzyme was checked for shelf life for a period of 1 year at room temperature.

\section{Feather processing and feather meal production}

Procurement of feather and feather processing: Chicken feather were procured from the local market. Feathers were washed with detergent and detergent was removed by several washing with tap water followed by distilled water. Washed feather were dried at $80^{\circ} \mathrm{C}$ for $6 \mathrm{~h}$ and were used for subsequent experimentation.

Standard protocol for feather degradation: Feather (2.5g) was autoclaved at $15 \mathrm{psi}$ for $15 \mathrm{~min}$ in a $250 \mathrm{ml}$ flask containing $25 \mathrm{ml}, 25 \mathrm{mM}$ $\mathrm{pH} 8$ phosphate buffers. Volume was made upto $50 \mathrm{ml}$ with properly diluted enzyme. Flasks were kept at $150 \mathrm{rpm}, 50^{\circ} \mathrm{C}$ for $12 \mathrm{~h}$ or till specified time. After degradation, feather meal was filtered through $2 \mathrm{~mm}$ sieve and residual feather were dried at $80^{\circ} \mathrm{C}$ till constant weight. Percent degradation was calculated on the basis of dry weight. Experiments were set up in triplicate and repeated twice. Data is presented as mean $( \pm \mathrm{SD})$.

\section{Process Parameters}

\section{Effect of enzyme concentration}

Effect of enzyme concentration on feather degradation was checked using $150-1500 \mathrm{U}$ keratinase on $2.5 \mathrm{~g}$ feather in $50 \mathrm{ml}$ volume, for a period of $12 \mathrm{~h}$ and percent degradation was studied using dry weight method.

\section{Effect of temperature and time}

Feather degradation was studied as a function of time for the period of $2 \mathrm{~h}-12 \mathrm{~h}$ or till complete degradation at $37^{\circ} \mathrm{C}$ and $50^{\circ} \mathrm{C}$ using $2.5 \mathrm{~g}$ from in $50 \mathrm{ml}$ volume and $1200 \mathrm{U}$ enzyme under standard conditions. Percent feather degradation, protein release and residual keratinase activity was determined after every $2 \mathrm{~h}$. Structural changes in feather were also analyzed by scanning electron microscopy (SEM). Feather were washed with $50 \mathrm{mM}$ phosphate buffer and dried at room temperature for scanning studies. Feather were coated with gold particle and observed using scanning electron microscopy (LEO 435VP SEM, Carl Zeiss NTS, GmbH, Germany) at Department of Anatomy, All India Institute of Medical Sciences, New Delhi, India, Department of Science and Technology supported service centre.

\section{Scale-up}

Keratinase degradation was further scaled up for degradation of $5,10,1520$ and $25 \mathrm{~g}$ feather in a $2 \mathrm{~L}$ flask at $\mathrm{pH} 8$ and $50^{\circ} \mathrm{C}$ under optimized condition (5\%w/v feather, 150rpm and $1200 \mathrm{U}$ enzyme $/ 2.5 \mathrm{~g}$ feather).

\section{Pre-soaking and boiling of feather}

Pre-soaking and boiling method was substituted for autoclaving. Twenty five gram feather was soaked in $250 \mathrm{ml}$ water for $2 \mathrm{~h}$ and boiled for 10-20 min with intermittent mixing instead of autoclaving in standard protocol. It was cooled to room temperature and 12000U enzyme along with remaining $50 \%$ moisture i.e. $250 \mathrm{ml} \mathrm{pH} 8$ buffer was added and mixed properly. It was kept at $50^{\circ} \mathrm{C}$ and $150 \mathrm{rpm}$ till complete degradation of feather. Feather meal was dried at $80^{\circ} \mathrm{C}$ and was ground to form homogenous powder.

\section{Amino acid and CHN analysis of feather meal}

One $g$ of feather meal powder was hydrolyzed with $10 \mathrm{ml}$ of $6 \mathrm{~N} \mathrm{HCl}$ at $60^{\circ} \mathrm{C}$ for $12 \mathrm{~h}$, filtered. Filtrate was concentrated by speed vac and analyzed for amino acid profiling by HPLC (Agilent 1100 HP-HPLC) after derivatization with orthopthalaldehyde. Sample was run into the Aminex column using mobile phase $(\mathrm{A}(20 \mathrm{mM}$ sodium acetate + $0.018 \%$ triethylamine $)$ and B $(20 \%$ of $100 \mathrm{mM}$ sodium acetate $+40 \%$ methanol $+40 \%$ acetonitrile) with the flow rate of $0.5 \mathrm{ml} / \mathrm{min}$ at $40^{\circ} \mathrm{C}$ and detected at $338 \mathrm{~nm}$ using VW detector. Amino acids were quantified using HPLC standards at Shanker Nethrayala, Chennai, India.

Carbon, nitrogen, sulfur and hydrogen contents of feather meal were analyzed using $1 \mathrm{~g}$ feather meal powder at USIC facility, Delhi University, North campus, Delhi, India Using CHNS analyzer (Elementar, Vario El, Germany).

\section{In-vitro digestibility of feather meal}

For in-vitro digestibility, $1 \mathrm{~g}$ feather meal was resuspended in $10 \mathrm{ml}$, $2 \mathrm{~N} \mathrm{HCl}, 2 \mathrm{mg} / \mathrm{ml}$ pepsin was added and mixture was incubated $37^{\circ} \mathrm{C}$ for $2 \mathrm{~h}$. Further, $\mathrm{pH}$ of the mixture was adjusted to $\mathrm{pH} 8$ by adding $2 \mathrm{M}$ sodium bicarbonate and $2 \mathrm{mg} / \mathrm{ml}$ trypsin was added and incubated at $37^{\circ} \mathrm{C}$ for $16 \mathrm{~h} \mathrm{[11].} \mathrm{After} \mathrm{pepsin} \mathrm{and} \mathrm{trypsin} \mathrm{treatment} \mathrm{peptide} \mathrm{release}$ was measured at $280 \mathrm{~nm}$. Percent digestibility was calculated by total protein released/ total protein of $1 \mathrm{~g}$ feather.

\section{Results and Discussion}

Keratinase from Bacillus licheniformis ER-15 was produced in soy flour feather medium for $60 \mathrm{~h}$ in a $2 \mathrm{~L}$ flask as reported earlier [10]. Fermentation broth was kept at room temperature for $24 \mathrm{~h}$ which allowed the settling of $>90 \%$ bacterial biomass onto feather meal. Feather are made up hydrophobic amino acids which may have facilitated settling of microbial cells on the degraded feather specially the Bacillus sp. which is known to produce biosurfactant making the cell surface hydrophobic $[1,12]$. Sedimentation step can easily substitute centrifugation in downstream processing of fermentation broth of biosurfactant producing microbes.

The keratinase was concentrated with $85 \%$ ammonium sulphate saturation which resulted in $>80 \%$ enzyme recovery. Concentrated enzyme was stored at room temperature with shelf life of upto a year with almost no loss in activity (data not shown).

\section{Standardization of feather degradation}

Keratinase from $B$. licheniformis ER-15 exhibited maximum activity at $\mathrm{pH} 11$ and $70^{\circ} \mathrm{C}[10]$. Although, alkaline $\mathrm{pH}$ and high temperature would facilitate rapid feather degradation by reducing disulfide bonds [2] but is not often recommended for the direct use of feather meal in feed due to loss of some essential amino acids $[3,13]$. Therefore, feather degradation was studied at $\mathrm{pH} 8$ and $50^{\circ} \mathrm{C}$ where present keratinase exhibited $>60 \%$ activity [10]

\section{Effect of enzyme concentration}

Degradation of feather was observed to be a linear function of enzyme concentration with $>600 \mathrm{U}$ (Figure 1 ). No visible degradation was observed upto $600 \mathrm{U}$ even after prolonged treatment. By increasing enzyme concentration from 600 to $900 \mathrm{U}, 60 \%$ feather degradation was achieved which increased to $>90 \%$ with dissolution of shaft as concentration was increased to $1200-1500 \mathrm{U} / 2.5 \mathrm{~g}$ feather. Feather degradation using keratinase have been reported in presence of reducing agents like hypochlorite, dithiothretol, glutathione or in presence of live cells which provides reducing environment $[1,14]$. Majority of the feather meal production involves fermentation using keratinolytic microbes and subsequent fermentation broth was regarded as feather meal 
Citation: Tiwary E, Gupta R (2012) Rapid Conversion of Chicken Feather to Feather Meal Using Dimeric Keratinase from Bacillus licheniformis ER15. J Bioprocess Biotech 2:123 doi: 10.4172/2155-9821.1000123

Page 3 of 5

$[2,6,11,15]$. During fermentation, feather degradation is supposed to be achieved by co-operative action of protease and cell redox [16-18]. In this context, present process is better than the existing ones since no fermentation is required for feather meal production.

\section{Effect temperature on feather degradation}

Feather degradation was studied at $37^{\circ} \mathrm{C}$ and $50^{\circ} \mathrm{C}$ and $>90 \%$ degradation was observed after $24 \mathrm{~h}$ at $37^{\circ} \mathrm{C}$ and $8 \mathrm{~h}$ at $50^{\circ} \mathrm{C}$. Further dissolution of shaft was observed only at $50^{\circ} \mathrm{C}$. complete degradation at $50^{\circ} \mathrm{C}$ may be a result of faster breakdown of disulfide bonds at higher temperature which may have resulted in dissolution of shaft [1]. Further, the present enzyme has optimal activity at $70^{\circ} \mathrm{C}$ with $>90 \%$ activity at $50^{\circ} \mathrm{C}$ and $67 \%$ at $37^{\circ} \mathrm{C}[10]$. Thus, the faster degradation at $50^{\circ} \mathrm{C}$ may be result of both enzyme concentration and temperature.

\section{Protein release and structural changes during feather degra- dation}

Protein release and structural changes in feather was studied at $50^{\circ} \mathrm{C}$ (Figure 2). From figure 2, it can be observed that maximum protein was released in the first $2 \mathrm{~h}$ with only $20 \%$ degradation (Figure $2 \mathrm{~A}$ ) and not much visible changes in feather (Figure $2 \mathrm{~B}$ ). First visual observation of feather degradation was made with shedding of barbules after $4 \mathrm{~h}$ of incubation accompanied by additional $20 \%$ loss in weight. However, no substantial release of protein in supernatant was observed as was after first $2 \mathrm{~h}$. Similar trend in protein release was observed on further incubation upto $8 \mathrm{~h}$ where complete degradation of feather was obtained. This suggests that, smaller peptides are released mostly during first $2 \mathrm{~h}$ of degradation and later on most of the protein remains in the feather meal. This is the first report where keratinase alone could degrade feather completely within $8 \mathrm{~h}$. Hydrothermal hydrolysis of degradation also required longer time $(16 \mathrm{~h})$ and high temperature $\left(120^{\circ} \mathrm{C}\right)$ for feather degradation [1]. Further microbial degradation of feather generally requires more than $24 \mathrm{~h}$ which may extend upto 5 week with the microbe used [2].

During feather degradation enzyme stability was also studied and $80 \%$ enzyme activity was recovered at $50^{\circ} \mathrm{C}$ after $8 \mathrm{~h}$ which is higher

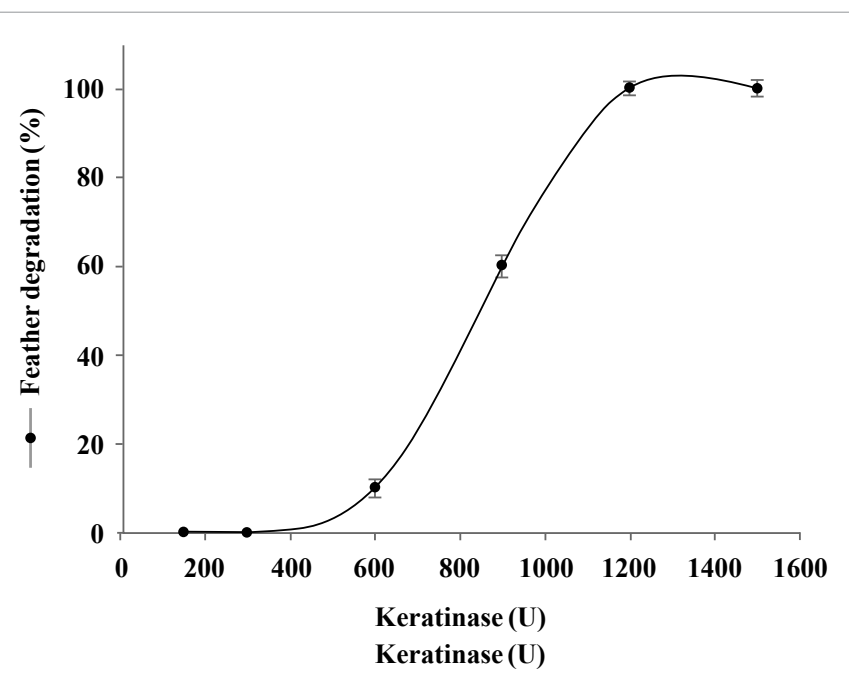

Figure 1: Feather degradation as a function of enzyme

Feather degradation was performed with $250 \mathrm{mg}$ feather in $\mathrm{pH} 8$ buffer at $50^{\circ} \mathrm{C}$ $150 \mathrm{rpm}$ for $12 \mathrm{~h}$. Percent degradation was calculated by measuring residua feather, dried at $80^{\circ} \mathrm{C}$ for $12 \mathrm{~h}$. than earlier report where half life was $5 \mathrm{~h}$ at $50^{\circ} \mathrm{C}$. This observation suggests that thermo-stability of present keratinase was enhanced in presence of substrate. This is in confirmation with commonly observed phenomenon that substrate protects enzyme against thermal destabilization [19].

\section{Scale up}

Feather degradation was scaled upto $5-25 \mathrm{~g}$ feather in $2 \mathrm{~L}$ flask in standardized condition and $>90 \%$ degradation was achieved within $12 \mathrm{~h}$ in $>10 \mathrm{~g}$ feather. Thus, complete feather degradation of feather in large volume was obtained in same condition and process was successfully scaled up.

\section{Presoaking and boiling method}

Since, for bulk degradation, $5 \% \mathrm{w} / \mathrm{v}$ feather involves large volume and would lead to cumbersome downstream process therefore pre-soaking and boiling was attempted with $25 \mathrm{~g}$ feather. Feather was soaked in $250 \mathrm{ml}$ water for $2 \mathrm{~h}$ and approximately $50 \%$ absorption of water. This pre-soaked feather was boiled for 10-20min and cooled till room temperature. Further $250 \mathrm{ml}$ enzyme (12000U) in pH 8 buffer was added to the boiled feather and $>90 \%$ feather degradation was achieved at $50^{\circ} \mathrm{C}$ within $12 \mathrm{~h}$. This process formed a thick meal which was dried, ground and stored directly (Figure 3 ).

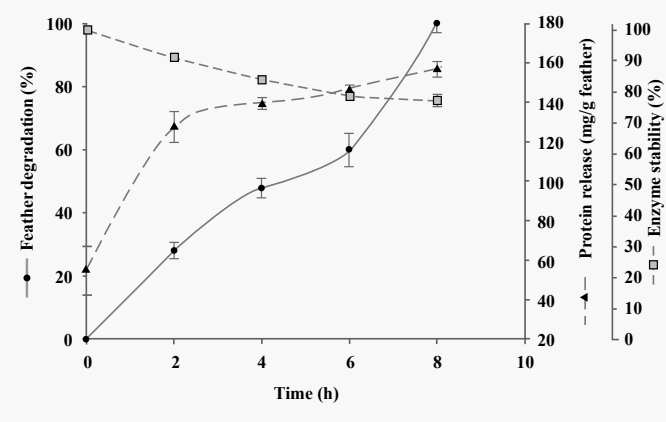

A.

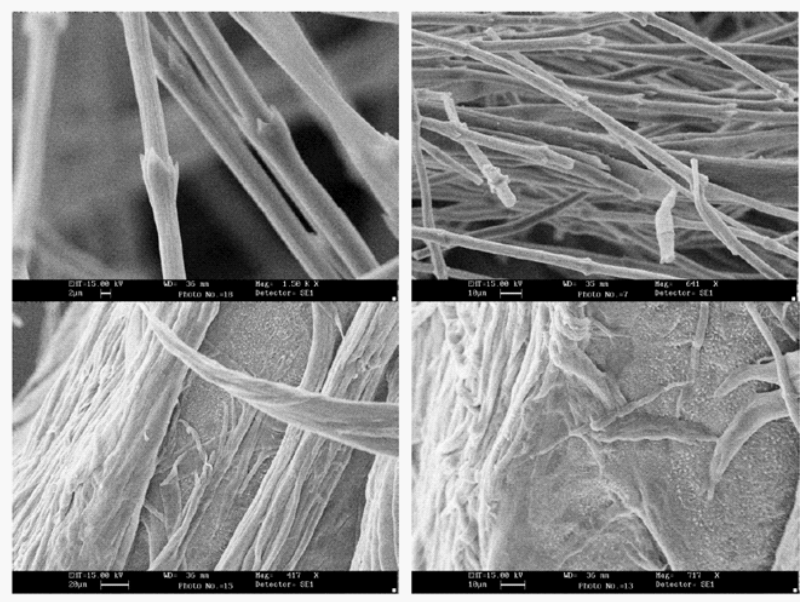

B.

Figure 2: Time kinetics (A) and structural changes (B) of feather during degradation.

A. Feather degradation was performed at $\mathrm{pH} 8,50^{\circ} \mathrm{C}$ and $150 \mathrm{rpm}$ till complete degradation.

B. Structure changes of feather at $0 \mathrm{~h}(\mathrm{a}), 2 \mathrm{~h}(\mathrm{~b}), 4 \mathrm{~h}(\mathrm{c})$ and $6 \mathrm{~h}(\mathrm{~d})$ after enzyme addition. 
Citation: Tiwary E, Gupta R (2012) Rapid Conversion of Chicken Feather to Feather Meal Using Dimeric Keratinase from Bacillus licheniformis ER15. J Bioprocess Biotech 2:123 doi: 10.4172/2155-9821.1000123

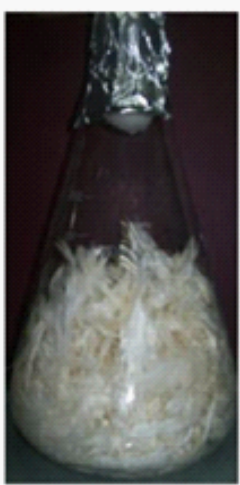

A

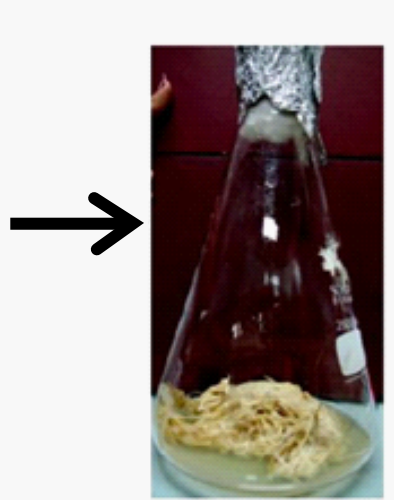

B

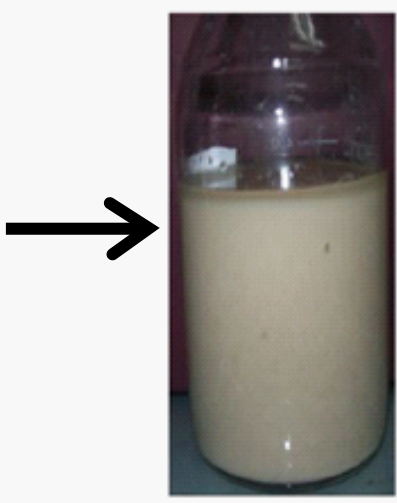

C

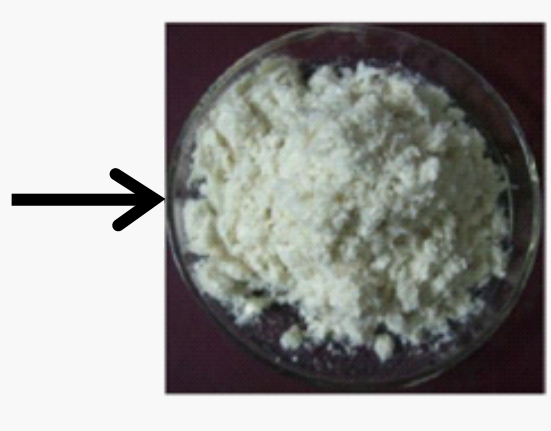

D

Figure 3: Various step of conversion of feather to feather meal. A. $25 \mathrm{~g}$ feather before pre-soaking and boiling, B. Feather after pre-soaking and boiling, C. Feather meal after $12 \mathrm{~h}$ with $12,000 \mathrm{U}$ enzyme treatment, D. Dried feather meal.

\begin{tabular}{|c|c|c|c|c|c|}
\hline Amino acid & $\begin{array}{l}\mathrm{mg} / \mathrm{g} \text { of feather } \\
\text { (present work) }\end{array}$ & $\begin{array}{l}\text { Steam hydrolyzed mg/g } \\
\text { feather (Eggum, 1970) }\end{array}$ & $\begin{array}{l}\text { acid hydrolyzed mg/g } \\
\text { feather (Eggum, 1970) }\end{array}$ & $\begin{array}{l}\mathrm{mg} \text { amino acid/g CP } \\
\text { (present work) }\end{array}$ & $\begin{array}{l}\mathrm{mg} \text { amino acid/g CP } \\
\text { (Grazziotin et al., 2006) }\end{array}$ \\
\hline Aspartic acid & 51 & - & - & 55.85 & 57.8 \\
\hline Glutamic acid & 56.1 & - & - & 61.45 & 92.2 \\
\hline Serine & 73.8 & - & - & 80.85 & 108.3 \\
\hline Histidine & 65.9 & 7.2 & 6.3 & 72.15 & 9.3 \\
\hline Glycine & 51.05 & - & - & 55.9 & 59.6 \\
\hline Threonine & 50.9 & 4.84 & 4.87 & 55.75 & 36.6 \\
\hline Alanine & 46.3 & - & - & 50.7 & 54.2 \\
\hline Arginine & 32.85 & 2.08 & 2.3 & 35.95 & 84.3 \\
\hline Tyrosine & 37.85 & 2.8 & 3.11 & 41.45 & 32.9 \\
\hline Valine & 33.15 & 7.25 & 7.73 & 36.3 & 85.6 \\
\hline Methionine & 31.6 & .72 & 0.76 & 34.6 & 17.0 \\
\hline Phenyl alanine & 69.95 & 4.61 & 4.85 & 76.6 & 54.2 \\
\hline Isoleucine & 51.85 & 4.82 & 5.55 & 56.8 & 62.8 \\
\hline Leucine & 17.15 & 8.25 & 8.27 & 18.75 & 66.9 \\
\hline Lysine & 14.85 & 2.08 & 2.23 & 16.25 & 24.1 \\
\hline
\end{tabular}

Table 1: Amino acid composition of feather meal and comparison with reported feather meals.

\section{Quality of feather meal}

Quality of feather meal was checked by CHN analysis as well as amino acids profiling. The feather meal contained $14 \% \mathrm{w} / \mathrm{w}$ nitrogen, $44 \% \mathrm{w} / \mathrm{w}$ carbon, $3.2 \% \mathrm{w} / \mathrm{w}$ sulfur and $1.4 \% \mathrm{w} / \mathrm{w}$ hydrogen which suggests that feather meal is a protein rich meal with $87 \%$ protein by weight. Amino acid composition of feather meal is presented in Table 1 and compared with steam cooked, acid hydrolyzed, culture supernatant hydrolyzed (CSH) feather meal $[11,20]$. Enzymatic hydrolysis of feather meal was observed to be rich in essential amino acids in comparison to steam cooked/ acid hydrolyzed feather meal. Amino acid content of present feather meal was comparable to $\mathrm{CSH}$ produced by keratinolytic bacterium Vibrio kr6 [11] except for few quantitative differences. The present feather meal had higher content of essential amino acids histidine, phenylalanine, methionine and threonine while $\mathrm{CSH}$ revealed high content of glutamate, serine, arginine and leucine. These differences may be due to the different processes used for feather degradation. Since the CSH was a result of crude supernatant after feather degradation during fermentation by Vibrio kr 6 and present process was a cell free enzymatic degradation.

In-vitro digestibility of feather meal was determined by pepsin fol- lowed by trypsin treatment. Feather meal was found to be digestible by pepsin and trypsin by releasing $670 \mathrm{mg}$ protein/g feather meal after $18 \mathrm{~h}$ of digestion. In-vitro digestibility results showed that digestibility of the present feather meal is 0.734 i.e. $73.4 \%$ which is better than commercial feather meal (0.578) or milled feather (0.096) and comparable to whole cell hydrolysate $(\mathrm{WCH})(0.834)$ feather meal produced by fermentation [11]. This suggests that present feather meal can be used as feed for chickens, cattle and fish as reported earlier for feather meal produced by fermentation [21].

\section{Conclusion}

The present process of bioconversion of feather into feather meal is completely an enzymatic process. To the best of our knowledge, this is the only process where no additional redox has been provided. The process is not only simple and time saving but at the same time economically viable as it does not require any bioreactor for feather degradation. Thus, bulk feather can be easily recycled into feather meal using keratinase from Bacillus licheniformis ER-15 within 12h.

\section{Acknowledgments}

Authors thank to Delhi University for Dean Research grant (R\&D/2010/1311) and DU-DST PURSE grant for financial assistance and Ekta Tiwary thanks Counci 
Citation: Tiwary E, Gupta R (2012) Rapid Conversion of Chicken Feather to Feather Meal Using Dimeric Keratinase from Bacillus licheniformis ER15. J Bioprocess Biotech 2:123 doi: 10.4172/2155-9821.1000123

Page 5 of 5

of Scientific and Industrial Research (CSIR), New Delhi for Senior Research Fellowship grant (9145(1080)/2011-EMRI). Department of Anatomy, All India Institute of Medical Sciences, New Delhi, India is also acknowledged for providing SEM facility.

\section{References}

1. Onifade AA, Al-Sane NA, Al-Musallam AA, Al-Zarban S (1998) A review: Potentials for biotechnological applications of keratin-degrading microorganisms and their enzymes for nutritional improvement of feathers and other keratins as livestock feed resources. Bioresour Technol 66: 1-11.

2. Gupta R, Ramnani $P$ (2006) Microbial keratinases and their prospective applications: an overview. Appl Microbiol Biotechnol 70: 21-33.

3. Brandelli A (2008) Bacterial keratinases: Useful enzymes for bioprocessing agroindustrial wastes and beyond. Food Bioprocess Technol 1: 105-116.

4. Vasileva-Tonkova E, Gousterova A, Neshev G (2009) Ecologically safe method for improved feather wastes biodegradation. Int Biodeterior Biodegrad 63: 1008-1012.

5. Coward-Kelly G, Agbogbo FK, Holtzapple MT (2006) Lime treatment of keratinous materials for the generation of highly digestible animal feed: 2 . animal hair. Bioresour Technol. 97: 1344-1352.

6. Brandelli A, Daroit D J, Riffel A (2010) Biochemical features of microbial keratinases and their production and applications. Appl Microbiol Biotechnol 85: 1735-1750.

7. Papadopolous MC, El-Boushy AR, Roodbeen AE, Ketelaars EH (1986) Effects of processing time and moisture content on amino acids composition and nitrogen characteristics of feather meal. Animal Feed Sci Technol 14: 279-290.

8. Wang X, Parson CM (1997) Effect of processing systems on protein quality of feather meal and hog hair meals. Poultry Sci 76: 491-496.

9. Zaghloul TI, Embaby AM, Elmahdy AR (2011) Biodegradation of chicken feathers waste directed by Bacillus subtilis recombinant cells: Scaling up in a laboratory scale fermentor. Bioresour Technol 102: 2387-2393.
10. Tiwary E, Gupta R (2010) Medium optimization for a novel 58 kDa dimeric keratinase from Bacillus licheniformis ER-15: Biochemical characterization and application in feather degradation and dehairing of hides. Bioresour Technol 101: 6103-6110.

11. Grazziotin A, Pimentel FA, de Jong EV, Brandelli A (2006) Nutritional improvement of feather protein by treatment with microbial keratinase. Animal Feed Sci Technol 126: 135-144.

12. Czaczyk K, Bialas W, Myszka K (2008) Cell surface hydrophobicity of Bacillus spp. as a function of nutrient supply and lipopeptides biosynthesis and its role in adhesion. Pol J Microbiol 57: 313-319.

13. Hood CM, Healy MG (1994) Bioconversion of waste keratins: wool and feathers. Resources Conversion Recycling 11: 179-188.

14. Karthikeyan R, Balaji S, Sehgal PK (2007) Industrial applications of keratins-a review. J Sci Ind Res 66: 710-715.

15. Williams CM, Lee CG, Garlich JD, Shih JCH (1991) Evaluation of a bacteria feather fermentation product, feather lysate, as a feed protein. Poult Sci 70 : 85-90.

16. Bockle B, Muller R (1997) Reduction of disulfide bonds by Streptomyces pactum during growth on chicken feathers. Appl Environ Microbiol 63: 790-792.

17. Yamamura S, Morita Y, Hasan Q, Yokoyama K, Tamiya E (2002) Keratin degradation: a cooperative action of two enzymes from Stenotrophomonas sp. Biochem Biophys Res Commun 294: 1138-1143.

18. Ramnani P, Gupta R (2007) Keratinases vis-à-vis conventional proteases and feather degradation. World J Microbiol Biotechnol 23: 1537-1540.

19. Sharpe DJ, Wong LJ (1990) Effect of substrates on the thermal stability of nuclear histone acetyltransferase. Biochimie 72: 323-326.

20. Eggum BO (1970) Evaluation of protein quality of feather meal under different treatments. Acta Agricultura Scandinavic 20: 230-234.

21. Bertsch A, Coello N (2005) A biotechnological process for treatment and recycling poultry feathers as a feed ingredients. Bioresour Technol 96: 1703-1708. 